\title{
Isolation and characterization of hybrid poplar galactinol synthases
}

\author{
Faride Unda ${ }^{1 *}$, Shawn Mansfield ${ }^{2}$ \\ From IUFRO Tree Biotechnology Conference 2011: From Genomes to Integration and Delivery \\ Arraial d Ajuda, Bahia, Brazil. 26 June - 2 July 2011
}

The raffinose family of oligosaccharides (RFOs) likely fulfill at least few major physiological roles in plants, translocation of carbon in the phloem, storage in sink tissues, and as putative biological agents to combat both abiotic and biotic stress [1-3]. The synthesis of galactinol from myo-inositol + UDP-galactose, by galactinol synthase (GolS), is considered a key regulatory step in RFO synthesis [4].To investigate the functional roles of this class of compounds in trees, two cDNAs that encode galactinol synthase (GolS), were identified and cloned from hybrid poplar ( $P$. alba $\times$ grandidentata $)$. Phylogenetic analyses of the Populus GolS isoforms with other known galactinol synthases suggested a putative role for these enzymes during biotic or abiotic stress in hybrid poplar. The predicted protein sequences of both isoforms (PaxgGolSI and PaxgGolSII) showed characteristics of galactinol synthases from other species, including a serine phosphorylation site at position 266 and the pentapeptide hydrophobic domain ASAAP [5]. Kinetic analyses of recombinant PaxgGolSI and PaxgGolSII resulted in $K_{m}$ values for UPD-galactose of 0.79 and $0.65 \mathrm{mM}$ and $\mathrm{V}_{\max }$ values of 660.4 and $1245 \mathrm{nM} \mathrm{min}{ }^{-1}$, respectively. PaxgGolSI inherently possessed broader $\mathrm{pH}$ range and temperature sensitivity when compared to PaxgGolSII. Interestingly, spatial and temporal expression analyses revealed that PaxgGolSII transcript levels varied seasonally, while PaxgGolSI did not, thereby implying a temperature-regulated transcriptional control of this gene in addition to the observed thermosensitivity of the respective enzyme. Based on this evidence, we suggest that PaxgGolSI may be involved in basic metabolic activities (i.e.storage), while PaxgGolSII is likely involved in seasonal mobilization of carbohydrates.

\footnotetext{
* Correspondence: farideu@interchange.ubc.ca

'Wood Science Department -University of British Columbia, Canada
}

Full list of author information is available at the end of the article

\section{Author details}

${ }^{1}$ Wood Science Department -University of British Columbia, Canada. ${ }^{2}$ Wood

Science Department- University of British Columbia, Canada.

Published: 13 September 2011

\section{References}

1. Taji T, Ohsumi C, luchi S, Seki M, Kasuga M, Kobayashi M, et al: Important roles of drought- and cold-inducible genes for galactinol synthase in stress tolerance in Arabidopsis thaliana. Plant Journal 2002, 29(4):417-426.

2. Panikulangara TJ, Eggers-Schumacher G, Wunderlich M, Stransky H, Schoffl F: Galactinol synthase1. A novel heat shock factor target gene responsible for heat-induced synthesis of raffinose family oligosaccharides in Arabidopsis. Plant Physiology 2004, 136(2):3148-3158.

3. Philippe RN, Ralph SG, Mansfield SD, Bohlmann J: Transcriptome profiles of hybrid poplar (Populus trichocarpa $x$ deltoides) reveal rapid changes in undamaged, systemic sink leaves after simulated feeding by forest tent caterpillar (Malacosoma disstria). New Phytologist 2010, 188(3):787-802.

4. Keller F, Pharr DM: Metabolism of carbohydrates in sinks and sources: Galactosyl-sucrose oligosaccharides. In Photoassimilate distribution in plants and crops. New York: Marcel Dekker;Zamski E, \& Schaffer AA 1996:115-184.

5. Sprenger N, Keller F: Allocation of raffinose family oligosaccharides to transport and storage pools in Ajuga reptans: The roles of two distinct galactinol synthases. Plant Journal 2000, 21(3):249-258.

doi:10.1186/1753-6561-5-S7-P77

Cite this article as: Unda and Mansfield: Isolation and characterization of hybrid poplar galactinol synthases. BMC Proceedings 2011 5(Suppl 7):P77.

\section{Submit your next manuscript to BioMed Central} and take full advantage of:

- Convenient online submission

- Thorough peer review

- No space constraints or color figure charges

- Immediate publication on acceptance

- Inclusion in PubMed, CAS, Scopus and Google Scholar

- Research which is freely available for redistribution

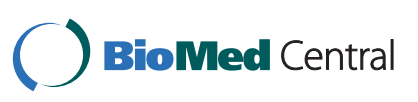

